\title{
Raised serum creatine phosphokinase activity in ankylosing spondylitis
}

\author{
ANDREI CALIN \\ From Guy's Arthritis Research Unit, Guy's Hospital, London
}

\begin{abstract}
Calin, A. (1975). Annals of the Rheumatic Diseases, 34, 244-248. Raised serum creatine phosphokinase activity in ankylosing spondylitis. Serum enzyme studies were made on 43 (37 male, 6 female) consecutive patients with ankylosing spondylitis. Serum creatine phosphokinase (CPK) activity was raised above $55 \mathrm{IU} / \mathrm{l}$ in $24(65 \%)$ of 37 male patients (range 29-165 IU/l, mean 68 ) as compared with $2(4 \%)$ out of 47 male controls (range 14-85 $\mathrm{IU} / 1$, mean $33 ; \mathrm{P}<0.001)$; levels were greater than $35 \mathrm{IU} / 1$ in six $(100 \%)$ out of six female patients (range $39-100 \mathrm{IU} / 1$, mean 56 ) as against one (3\%) of 35 female controls (range 3-106 IU/1, mean 16; P < 0.001). The recognized pitfalls in interpreting CPK activity were avoided. In all of sixteen randomly selected patients isoenzyme studies confirmed that muscle is the source of the enzyme. There was a significant correlation between CPK activity and both spinal flexion and the reciprocal of finger-to-floor distance $(\mathrm{P}<0.05$ in each case).
\end{abstract}

Ankylosing spondylitis (AS) is a chronic inflammatory disease of unknown aetiology. It differs from rheumatoid and other inflammatory arthropathies in the pattern of joint involvement, male preponderance, and tendency to bony ankylosis. The systemic effects of rheumatoid disease are well known (British Medical Journal, 1973), and although the extraarticular manifestations of AS occur less frequently, iritis (Blumberg and Ragan, 1956), cardiac and pulmonary involvement (Graham and Smythe, 1958; British Medical Journal, 1971), and amyloidosis (Cruickshank, 1969) are well recognized.

In searching for evidence of systemic disease it became apparent that a large proportion of patients with AS did have a raised serum creatine phosphokinase (CPK). This paper is a study of serum CPK activity in 43 consecutive patients with AS.

Although raised serum CPK activity is a sensitive indicator of myocardial necrosis (Dreyfus, Schapira, Resnais, and Scebat, 1960) and disorders of striated muscle (Fowler and Pearson, 1964), Nevins, Saran, Bright, and Lyon (1973) stressed that abnormal values may occur in a variety of extramuscular and extracardiac conditions. This study was designed to allow for these influences and controls were picked from outpatients with both inflammatory and noninflammatory disease.

\section{Patients and methods}

Forty-three consecutive patients with AS were seen at Guy's Hospital. The control group consisted of ambulaAccepted for publication October 14, 1974. Present address of author: Dept. of Medicine (Immunology-S.102), Stanford University School of Medicine, Stanford, Calif. 94305, U.S.A. tory outpatients with noninflammatory disorders (includo ov ing prolapsed intervertebral discs and osteoarthrosis) and inflammatory joint disorders other than AS (includin polymyalgia rheumatica and rheumatoid arthritis). Tab I summarizes the sex and age distribution for patients and controls and duration of disease for patients. The majority of both the patient and control group had received phenylbutazone or indomethacin.

Diagnosis was made on clinical grounds and confirmed by the classical appearances of radiographs of the sacroiliac joints and spine (Bennett and Wood, 1968). Furthermore, analysis of the histocompatability status, which showed that all patients were HL-A 27 positive, helped to confirm the diagnosis in all 35 patients tested (Calin, Grahame, Tudor, and Kennedy, 1974). A full physical examination was made, including chest expansion, trunk movements (Moll and Wright, 1971), and finger-to-floor measurement on full forward flexion. Anterior spinal flexion was measured as the distraction, on flexion, of two points $5 \mathrm{~cm}$ below and $10 \mathrm{~cm}$ above the lumbosacral junction. Haematological and biochemical investigations were performed, including assays of alkaline phosphatase, serum aspartate amino transferase (SGOT), and CPK. Immunological assessment included a search for antimuscle antibodies. Sera from sixteen randomly selected individuals were analysed for CPK isoenzymes (CorningEel electrophoresis system).

A pilot study of 10 cases was performed (a) to assess the correlation of age with CPK activity and (b) to determine the persistence of a normal or abnormal CPK level in each individual on 3 separate occasions. CPK estimations were carried out by the Nielsen and Ludvigsen (1963) and Rosalki(1967) modification of the method of Oliver (1955).

In all patients and controls studied blood samples were taken at the same time of day and the time interval between 
Table I Distribution of sex, age, and duration of disease in patient group, and sex and age in controls

\begin{tabular}{|c|c|c|c|}
\hline & Number & $\begin{array}{l}\text { Age range (mean) } \\
\text { (years) }\end{array}$ & $\begin{array}{l}\text { Duration of } \\
\text { disease range } \\
\text { (mean) (years) }\end{array}$ \\
\hline $\begin{array}{l}\text { Patients } \\
\text { Male }\end{array}$ & 37 & $18-69(40 \cdot 4)$ & $1-25(11)$ \\
\hline Female & 6 & $15-63(38 \cdot 2)$ & $1-20(8 \cdot 3)$ \\
\hline Total & 43 & $15-69(40 \cdot 1)$ & $1-25(10 \cdot 2)$ \\
\hline \multicolumn{4}{|l|}{ Controls } \\
\hline Male & 47 & $16-69(42 \cdot 2)$ & \\
\hline Female & 35 & $23-71(39 \cdot 1)$ & \\
\hline Total & 82 & $16-71(41 \cdot 3)$ & \\
\hline
\end{tabular}

Table II Relevant physical measurements in patients with $A S$

\begin{tabular}{|c|c|c|c|}
\hline Measurements & Range & Mean & $S D$ \\
\hline $\begin{array}{l}\text { Chest expansion }(\mathrm{cm}) \\
\text { Spinal flexion }(\mathrm{cm})\end{array}$ & $\begin{array}{r}1 \cdot 0-8 \cdot 0 \\
0-7 \cdot 0\end{array}$ & $\begin{array}{l}3 \cdot 7 \\
3 \cdot 7\end{array}$ & $\begin{array}{l}1 \cdot 8 \\
2 \cdot 4\end{array}$ \\
\hline $\begin{array}{l}\text { Finger-to-floor } \\
\text { measurement }(\mathrm{cm})\end{array}$ & $0-41$ & 19.9 & 11.9 \\
\hline
\end{tabular}

the collection of the samples and analysis was comparable. Any individual who had undergone any procedure known to raise CPK, including strenuous exercise (Vejjajiva and Teasdale, 1965) and intramuscular injections (Meltzer, Mrozak, and Boyer, 1970), or who was suffering from any disorder associated with a raised CPK (such as muscular dystrophy and cardiac disease) was excluded. Possible correlations of CPK activity with various physical, haematological, and biochemical variables were sought.

\section{Results}

The relevant physical measurements are given in Table II and the results of relevant haematological and biochemical investigations are summarized in Table III.

In the control group CPK levels showed the expected difference with sex $(\mathrm{t}=4.2 ; \mathrm{P}<0.01)$ but not with age (males $r=0.03, \mathrm{P}>0.1$; females $r=0.24$, $P>0 \cdot 1$ ). Table IV records the CPK levels in ten individuals on 3 separate occasions and clearly shows the reproducibility of the results obtained. Tables $\mathrm{V}$ (males) and VI (females) compare the results of CPK activity in the patient group with those of the controls; the latter are further subdivided into individuals with inflammatory and noninflammatory disorders. The results were analysed by Student's ' $t$ ' test.

In no patient were antismooth muscle or antistriated muscle antibodies detected. The result of the

Table III Relevant laboratory data in patient group

\begin{tabular}{|c|c|c|c|c|c|c|}
\hline \multirow[t]{2}{*}{ Investigation } & \multicolumn{2}{|c|}{$\begin{array}{l}\text { Patients } \\
\text { studied }\end{array}$} & \multirow[t]{2}{*}{$\begin{array}{l}\text { Normal } \\
\text { range }\end{array}$} & \multirow[t]{2}{*}{$\begin{array}{l}\text { Patient } \\
\text { range }\end{array}$} & \multirow[t]{2}{*}{ Mean $(S D)$} & \multirow[t]{2}{*}{$\begin{array}{l}\text { Abnormal } \\
\text { results }(\%)\end{array}$} \\
\hline & Male & Female & & & & \\
\hline Haemoglobin (g/dl) & 37 & $\overline{6}$ & $\begin{array}{l}13 \cdot 0-18 \\
11 \cdot 5-16\end{array}$ & $\begin{array}{l}11 \cdot 4-15 \cdot 1 \\
11 \cdot 1-13 \cdot 7\end{array}$ & $\begin{array}{l}13 \cdot 7(1 \cdot 0) \\
12 \cdot 4(0 \cdot 8)\end{array}$ & $\begin{array}{l}4 \text { low } \\
1 \text { low }\end{array}$ \\
\hline ESR (Westergren) $(\mathrm{mm} / \mathrm{h})$ & 37 & 6 & $0-12$ & $3-63$ & $21 \cdot 0(15 \cdot 4)$ & 27 high $(63 \%)$ \\
\hline $\begin{array}{l}\text { Serum } \\
\quad \text { aspartate amino } \\
\text { transferase }(\mathrm{mU} / \mathrm{ml})\end{array}$ & 37 & 6 & $1-16$ & $8-30$ & $15 \cdot 5(5 \cdot 1)$ & 13 high $(30 \%)$ \\
\hline $\begin{array}{l}\text { Alkaline } \\
\text { phosphatase (KA units) }\end{array}$ & 37 & 6 & $1-15$ & $7-21$ & $11 \cdot 9(2 \cdot 9)$ & 3 high $(5 \%)$ \\
\hline $\begin{array}{l}\text { Albumin }(\mathrm{g} / 100 \mathrm{ml}) \\
\text { Globulin }(\mathrm{g} / 100 \mathrm{ml})\end{array}$ & $\begin{array}{l}37 \\
37\end{array}$ & $\begin{array}{l}6 \\
6\end{array}$ & $\begin{array}{l}3 \cdot 0-5 \cdot 6 \\
2.0-3 \cdot 8\end{array}$ & $\begin{array}{l}3 \cdot 8-4 \cdot 7 \\
2 \cdot 0-4 \cdot 3\end{array}$ & $\begin{array}{l}4 \cdot 1(0 \cdot 4) \\
3 \cdot 0(0 \cdot 3)\end{array}$ & $\begin{array}{l}0 \\
1 \text { high }\end{array}$ \\
\hline
\end{tabular}

Table IV CPK levels in ten individuals, $A$ to $J$, on 3 separate occasions

\begin{tabular}{|c|c|c|c|c|c|c|c|c|c|c|}
\hline Visit & A & B & C & $\mathbf{D}$ & $\mathbf{E}$ & $\mathbf{F}$ & $\mathbf{G}$ & $\mathbf{H}$ & I & $\mathbf{J}$ \\
\hline $1 \mathrm{st}$ & 107 & 71 & 32 & 18 & 34 & 52 & 26 & 140 & 148 & 22 \\
\hline 2nd & 76 & 63 & 39 & 30 & 43 & 59 & 33 & 118 & 132 & 26 \\
\hline $3 r d$ & 96 & 68 & 34 & 37 & 46 & 55 & 29 & 120 & 140 & 27 \\
\hline
\end{tabular}

isoenzyme studies in sixteen patients revealed that in all cases the enzyme was derived from muscle rather than brain or heart.

In an attempt to correlate CPK activity with physical, haematological, and biochemical variables, a multiple regression analysis was performed comparing CPK activity with (1) duration of disease, (2) age, (3) chest expansion, (4) finger-to-floor distance, (5) spinal flexion, (6) ESR, and (7) serum globulins. The 
Table V Comparing CPK values (IU/l) for male patients and male controls in individuals with inflammatory and noninflammatory disorders

\begin{tabular}{|c|c|c|c|c|c|c|c|}
\hline Group & Total & $\begin{array}{l}\text { Number } \\
(>55 \text { IU } / l)\end{array}$ & Range & Mean $(S D)$ & $\%$ Abnormal & $\begin{array}{l}t \text { value for } \\
\text { control groups }\end{array}$ & $\begin{array}{l}t \text { value for } \\
\text { patient and } \\
\text { control groups }\end{array}$ \\
\hline Patients & $\overline{37}$ & 24 & $29-165$ & $67.9(30.9)$ & 65 & & \\
\hline $\begin{array}{l}\text { Controls: } \\
\text { Inflammatory }\end{array}$ & 17 & 0 & $16-55$ & $32 \cdot 7(14 \cdot 7)$ & 0 & 0.415 & $6 \cdot 79$ \\
\hline Noninflammatory & 30 & 2 & $14-85$ & $31 \cdot 0(10 \cdot 9)$ & 6 & Not significant & $(P<0.001)$ \\
\hline Total & 47 & 2 & $14-85$ & $\overline{33 \cdot 1(15 \cdot 2)}$ & 4 & & \\
\hline
\end{tabular}

Table VI Comparing CPK values (IU/l) for female patients and female controls in individuals with inflammatory and noninflammatory disorders

\begin{tabular}{|c|c|c|c|c|}
\hline \multirow{2}{*}{$\begin{array}{l}\text { Group } \\
\text { Patients }\end{array}$} & Total & $\begin{array}{l}\text { Number } \\
(>35 \text { IU } \mid l)\end{array}$ & \multicolumn{2}{|l|}{ Range } \\
\hline & 6 & 6 & $39-100$ & $6 \cdot$ \\
\hline $\begin{array}{l}\text { Controls : } \\
\text { Inflammatory }\end{array}$ & 18 & 0 & $8-34$ & \\
\hline Noninflammatory 1 & 17 & 1 & $3-106$ & \\
\hline Total & 35 & 1 & $3-106$ & 16 \\
\hline $\begin{array}{l}\text { Table VII Regression } \\
7 \text { variables }\end{array}$ & on anal & usis of $C$ & ini & \\
\hline Variables & $\mathbf{r}$ & Significa & nce level ( 1 & \\
\hline $\begin{array}{l}\text { Duration of disease } \\
\text { Age } \\
\text { Chest expansion } \\
\text { Finger-to-floor distance } \\
\text { Spinal flexion } \\
\text { ESR } \\
\text { Globulins }\end{array}$ & $\begin{array}{l}-0.0 \\
-0.1 \\
+0 \cdot 2 \\
-0.3 \\
+0 \cdot 4 \\
+0 \cdot 0 \\
-0.3\end{array}$ & $\begin{array}{ll}6 & >0.2 \\
0 & >0.2 \\
0 & >0.2 \\
6 & <0.05 \\
10 & <0.05 \\
6 & >0.2 \\
2 & >0.2\end{array}$ & & \\
\hline
\end{tabular}

only correlations to reach statistical significance were those of spinal flexion and the reciprocal of finger-tofloor distance, CPK correlating at a $5 \%$ level with both (Table VII).

\section{Discussion}

The results of the present study show that CPK activity is significantly increased in the majority of patients with AS. The mean value in the male group of AS patients was $67.9 \mathrm{IU}$ compared with $32.7 \mathrm{IU}$ in the control group $(P<0.001)$. The relative values for females were $56 \mathrm{IU}$ and $16.4 \mathrm{IU}$, respectively $(P<0.001)$.

There are many recognized pitfalls in interpreting serum CPK activity, and meaningful analysis must take into consideration various factors.

(1) Enzyme values vary with sex, the upper limit of

normal CPK in females being about two-thirds of that found in males (Fowler and Pearson, 1964). In this study the sexes were analysed separately and $\triangle$ showed comparable rises in CPK activity. The study $\overrightarrow{0}$ confirmed previous work (Munsat, Baloh, Pearson, $\exists$ and Fowler, 1973), showing that age is irrelevant.

(2) Strenuous physical exercise can cause a rise in CPK activity (Vejjajiva and Teasdale, 1965). This factor can be discounted in the present study since the $?$ control and patient groups contained individuals undertaking a comparable degree of physical exercise and physiotherapy.

(3) Raised serum enzyme activity is assumed to reflect enzyme release from diseased tissues, but iatro- $\frac{}{-}$ genic causes of tissue damage, including intramuscular $\rightarrow$ injection (Meltzer, 1970), surgery (Klein, Shell, and Sobel, 1973), and cardioversion (Sobel and Shell, N 1972) have a similar effect.

(4) Tissues other than myocardial and striated $N$ muscle contain CPK. Brain (Nevins and others, 1973 ) is richly endowed, and thus the serum enzyme level may be raised in psychosis and after 0 convulsions. Lung, which contains a lesser amount, may nevertheless release sufficient enzyme to in-? crease serum activity after pulmonary infarction $\underset{T}{T}$ (Perkoff, 1968).

(5) Finally, storage of the serum, laboratory tech- $\stackrel{\square}{\square}$ niques, and nature of the assay procedure may in- $\stackrel{\mathbb{D}}{\circ}$ fluence the results (Nevins and others, 1973). 
All these features have been borne in mind in the selection of both patients and controls in this study and the technical procedures have been identical in both groups. Two individuals from the male control group had an unexplained raised CPK. One had an osteoclastoma and the other osteoarthrosis. The single female control with a raised level had osteoarthrosis.

Although it is recognized that AS may be associated with extra-articular disease, evidence of a myopathy has not previously been described. To date no biopsy or electromyographical studies have been performed. Recently, alkaline phosphatase has been shown to be raised in AS (Kendall, Lawrence, Shuttleworth, and Whitfield, 1973). In the present study three patients had minimally raised levels, the mean for the group was 11.9 King Armstrong units. The rise in serum aspartate amino transferase (SGOT) was more impressive, however; 13 patients $(30 \%)$ had raised levels (range 8-30, mean $15.5 \mathrm{mU} / \mathrm{ml}$ ) and although controls were not studied it is probable that a similar mechanism underlies the rise in both CPK and SGOT.

The abnormally high CPK levels in the patient group cannot be explained in terms of a nonspecific enzymatic response to the presence of chronic inflammatory disease. The mean level for 37 male patients with AS was $67.9 \mathrm{IU} / \mathrm{l}$, and that for 17 male individuals with rheumatoid arthritis was $32.7 \mathrm{IU} / 1$ $(P<0.01)$. Comparable figures for six female patients and eighteen controls were $56 \mathrm{IU} / 1$ and $18.9 \mathrm{IU} / 1$, respectively $(\mathrm{P}<0.01)$ (Tables $\mathrm{V}$ and VI). Clearly, among the controls there was no difference in CPK values between individuals with inflammatory and those with noninflammatory disease $(P>0 \cdot 2)$.

The patients appeared to have normal muscle bulk with no obvious wasting. Furthermore, Hendrich, Kuthan, Tovarek, and Vitulova (1966) have shown that the serum of patients suffering with rheumatoid arthritis and secondary muscular wasting shows no abnormality of enzymatic pattern.

An immunological explanation should be considered. IgG antiglobulin is known to be raised in AS (Howell, Chamberlain, Perry, Torrigiani, and Roitt, 1972) but autoantibodies to striated muscle and other tissue components were not present in this series. In a separate study, altered cell-mediated immunity could not be shown (G. Panayi and A. Calin, unpublished, 1974).

Genetic factors may be important in view of the known association of AS with HL-A 27 (Schlosstein, Terasaki, Bluestone, and Pearson, 1973) and the awareness that CPK activity may be raised in another genetically determined condition: patients with muscular dystrophy and their healthy heterozygous relatives (Dreyfus and others, 1960).

Of the 7 variables studied only the relationship between CPK activity and spinal flexion and the reciprocal of finger-to-floor distance reached significance $(P<0.05)$ (Table VII). This might suggest that CPK activity is raised in those individuals who still have early (but perhaps more active) disease without ankylosis and thus remain able to flex the spine.

Since patients with prolapsed intervertebral discs and muscle spasm do not have a raised CPK, it is unlikely that persistent muscle spasm could account for the findings. It is possible that a true muscle pathology exists and this needs to be explored by further techniques including electromyographical and biopsy studies. Meanwhile, it seems that muscle involvement should be added to the recognized list of extraspinal manifestations of AS.

I thank Drs. H. Burry and R. Grahame for their support and advice; Drs. J. Liddell and W. Seymore for performing the isoenzyme and antibody studies; and Dr. S. Farrow for help with the statistical analysis.

\section{References}

BenNett, P. H., AND Wood, P. N. H. (eds.) (1968) 'Population Studies of the Rheumatic Diseases,' p. 456. Excerpta Medica, Amsterdam

BlumberG, B., AND RAGAN, C. (1956) Medicine, 35, 1 (The natural history of rheumatoid spondylitis)

British Medical Journal (1971), 3, 492 (The lungs in ankylosing spondylitis)

- (1973), 2, 651 (Extra-articular lesions of rheumatoid arthritis)

Calin, A., Grahame, R., TUDOR, M., AND KENNEDY, L. (1974) Lancet, 1, 874 (Ankylosing rheumatoid arthritis, ankylosing spondylitis and HLA antigens)

Cruickshank, B. (1960) Bull. rheum. Dis., 10, 211 (Pathology of ankylosing spondylitis)

Dreyfus, J. C., Schapira, G., Resnais, J., AND Scebat, L. (1960) Rev. Franç. Etud. clin. biol., 5, 386 (Serum creatine kinase in the diagnosis of myocardial infarction)

Fowler, W. M. JR., AND Pearson, C. M. (1964) Arch.phys. Med., 45, 117 (Diagnostic and prognostic significance of serum enzymes. I. Muscular dystrophy)

Graham, D. C., AND SMYTHe, H. A. (1958) Bull. rheum Dis., 9, 171 (The carditis and aortitis of ankylosing spondylitis)

Hendrich, F., Kuthan, F., TovareK, J., AND Vitulova, V. (1966) Scripta Medica, 39, 63 (The enzymatic pattern in the serum of rheumatoid patients related to muscular wasting)

Howell, F. A., Chamberlain, M. A., Perry, R. A., Torrigiani, G., ANd Roitt, I. M. (1972) Ann. rheum. Dis., 31, 129 (IgG antiglobulin levels in patients with psoriatic arthropathy, ankylosing spondylitis, and gout)

Kendall, M. J., Lawrence, D. S., Shuttleworth, G. R., AND Whitfield, A. G. W. (1973) Brit. med. J., 2, 235 (Haematology and biochemistry of ankylosing spondylitis) 
Klein, M. S., Shell, W. E., AND Sobel, B. E. (1973) Cardiovasc. Res., 7, 412 (Serum creatine phosphokinase isoenzymes after intramuscular injections, surgery, and myocardial infarction)

Meltzer, H. Y. (1970) Clin. chim. Acta, 33, 165 (Factors affecting serum creatine phosphokinase levels in the general population: the role of race, activity and age)

—, MrozaK, S., AND Boyer, M. (1970) Amer. J. med. Sci., 259, 42 (Effect of intramuscular injections on serum creatine phosphokinase activity)

Moll, J. M. H., AND Wright, V. (1971) Ann. rheum. Dis., 30, 381 (Normal range of spinal mobility. An objective clinical study)

Munsat, T. L., Baloh, R., Pearson, C. M., and Fowler, W. JR., (1973) J. Amer. med. Ass., 226, 1536 (Serum enzyme alterations in neuromuscular disorders)

Nevins, M. A., SARAN, M., Bright, M., AND LyON, L. J. (1973) Ibid., 224, 1382 (Pitfalls in interpreting serum creatine phosphokinase activity)

Nielsen, L., AND LudVigSEN, B. (1963) J. Lab. clin. Med., 62 , 159 (Improved method for determination of creatine kinase)

OLIVER, I. T. (1955) Biochem. J., 61, 116 (A spectrophotometric method for the determination of creatine phosphokinase and myokinase)

PeRKOFF, G. T. (1968) Arch. intern. Med., 122, 326 (Demonstration of creatine phosphokinase in human lung tissue)

RosAlKI, S. B. (1967) J. Lab. clin. Med., 69, 696 (An improved procedure for serum creatine phosphokinase determination)

Schlosstein, L., Terasaki, P. I., Bluestone, R., and Pearson, C. M. (1973) New Engl. J. Med., 288, 704 (High association of an HL-A antigen, W27, with ankylosing spondylitis)

Sobel, B. E., AND Shell, W. E. (1972) Circulation, 45, 471 (Serum enzyme determinations in the diagnosis and assessment of myocardial infarction)

Vejuajva, A., AND Teasdale, G. M. (1965) Brit. med.J., 1, 1653 (Serum creatine kinase and physical exercise) 